\title{
Political Science Funding Black Out in North America? Trends in Funding Should not be Ignored
}

David J. Plazek, Johnson State College

Alan Steinberg, University of Houston

ABSTRACT Recent actions in Congress that threaten political science funding by the National Science Foundation (NSF) have caught the attention of political scientists, but this was not the first attack and not likely to be the last. Less than one year ago, the Harper government ended the Understanding Canada program, an important source of funding for academics in the United States and abroad. This article stresses the value of the program and the importance of this funding steam by demonstrating what the grants have done both more generally as well as for the authors individually. In addition, by looking at the political process that led to the end of the Understanding Canada program and the similarities in the attacks on NSF political science funding, this article identifies potential reasons why these funds were and are at risk. We conclude by arguing that normative action in support of political science is a necessity for all political scientists.

"I think that however expensive an education may be, ignorance will probably cost our country more."-Representative Chaka

Fattah (PA), 2012

"Taxpayers will not stand for-nor should they-the funding of poster sites, leaflets or advertising. What people will support is funding for political education, for training, for party organization." -Former British Member of Parliment Peter Hain, 2006 (Bright 2006)

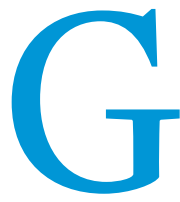

overnment funding of the social sciences is a crucial component to the knowledge development and research endeavors of scholars. Often times the critical value of these funds is misunderstood or cheapened as politicians look for ways to cut federal spending without looking like a "bad guy" to their constituents. While we have in our minds the recent congressional attack on the political science department of the National Science Foundation (NSF), other battles for funding have already been lost. In

David J. Plazek is an associate professor in the humanities department at Johnson State College. He is chair of the Institute of Canadian Studies at JSC and can be reached at david.plazek@jsc.edu.

Alan Steinberg is a PhD candidate in the department of political science at the University of Houston. He can be reached at afsteinberg@uh.edu.
May of 2012, Canada announced an end to a critical source of funding for academics in other countries, the Understanding Canada program. During the last 40 years, this program has been promoting knowledge and interest in Canada around the world.

It is often difficult to highlight the direct value of academic grants, but easy to point fingers at seemingly expensive programs when cutting discretionary spending is a potentially important political move. During the short debate over the second Flake Amendment, which effectively ended political science spending by the NSF, an opponent to the amendment noted, "You could probably bring a list of studies in front of the Congress from the National Science Foundation and get a laugh on any day. But these studies are important" (Representative Fattah (PA) 2012). The same holds true for the academic grants under the Understanding Canada program, and that is why we must tell their story and explain their value to political science.

\section{GRANTS AT WORK}

Many political scientists have already written about the important research that NSF has funded (Chenoweth and Lyall 2012; Gelman 2012; Nyhan 2012; Wilson 2012). However, few political scientists are aware of any of the programs Understanding Canada funded or how those programs provide direct impact to our 
discipline. Typically scholars from a variety of academic disciplines, including political science, received grants to defray travel costs to and from Canada under the conditions that they teach courses with extensive Canadian content in their home country within three to five years. The funds could also be used to develop Canadian institutes, bring in Canadian speakers, or enable student trips to Canada from foreign institutions of higher learning (Martin 2012).

Understanding Canada has been incredibly successful in meeting the original goals. The funding contributed to Canadian Studies programs in 39 countries and supports 7,100 foreign scholars (Blanchfield 2012). The program has been so effective that Australia and Japan copied the model and the US Department of State has promoted the approach to other countries (Meisel and Graham 2012). The modest budget of $\$ 5$ million is estimated to generate $\$ 70$ million a year to the Canadian economy according to an internal report prepared for the Department of Foreign Affairs in 2010 (Blanchfield 2012; The Canadian Press 2012; Martin 2012). For instance, the purchase of books, films, equipment, and the costs to study in Canada are estimated to be close to \$20 million (Meisel and Graham 2012). The ripple effect of the program's demise is felt around the globe and has shaken the International Council for Canadian Studies (ICCS) and the Association for Canadian Studies in the United States (ACSUS). Understanding Canada's grants are crucial to many Canadian studies programs.

\section{OUR WEEK IN CANADA}

One important organization that lost funding was the CONNECT program at SUNY Plattsburgh that seeks to promote the study of Canada in the United States. Should the program be described by someone like Representative Flake, he would no doubt see it as a waste, much like those in prime minister Stephen Harper's administration did given their decision to end it. However, the CONNECT program, like many other grant-funded research and initiatives under the Understanding Canada program, has had direct tangible benefits to academics including us, the authors, and political science, as we illuminate.

The CONNECT seminar was designed to introduce and engage participants with leading representatives from Canadian studies associations, Canadian foundations, and the Canadian government to provide a thorough policy grounding in the political, economic, and social realities of contemporary Canada and familiarize new American Canadianists with current curriculum and scholarly and professional opportunities (Center for the Study of Canada at SUNY Plattsburgh 2012). Jointly run by the Government of Canada and the Center for the Study of Canada at SUNY Plattsburgh the program works to identify, recruit, orientate, and mentor new Canadianists for American higher education. The program's concept is to promote the growth, development, and institutionalization of Canadian studies in the United States, through political science, history, anthropology, art, or other fields.

For us CONNECT involved a series of academic lectures, visits to culturally significant institutions, and a foray into government and politics. Lectures were on timely issues and provided by well-versed scholars including "Canadian Culture and Politics" by assistant dean Richard Nimijean, Carleton University; "Canadian Foreign Policy" by professor Claire Turenne-Sjolander, University of Ottawa; and "Canadian Media and Policy in the Internet Age" by professor Ira Wagman, Carleton University. Academic connections were formed through roundtables that allowed us to engage with the other participants as well as invited guests. These roundtables included introductions to various Canadian studies associations where we met with past president George Sulzner of the Association for Canadian Studies in the United States, executive director Cristina Frias of the International Council for Canadian Studies, and executive director Raymond Pelletier of the American Council for Quebec Studies, in addition to receiving an introduction to Fulbright Canada by director Michael Hawes.

Learning was not constrained to a classroom; we took a guided tour of the Canadian Museum of Civilization and visited the National Gallery of Canada to provide an educational experience on the history, art, and culture of Canada. We also visited multiple government offices including the Parliament of Canada that included a basic introduction to the history of the institution, the Supreme Court of Canada where we met with Roger Bilodeau, the Registrar of the Supreme Court of Canada, as well as Foreign Affairs and International Trade Canada where we received an introduction to the history and workings of the Canadian government and engaged government representatives on policy matters. To bring the experience "back home," we also met with representatives of the US Embassy in Canada to learn more about the American government's position and relationship with Canada. Finally, to bolster our ability to do academic research in Canada we visited Library and Archives Canada and a staff reference archivist showed us how to use the materials.

Taken together we all left the seminar learning something new about Canada or Canada/US relations. Legislators or bureaucrats might not see the value in such an opportunity. Instead they may relate it to a one-week paid vacation, instead of an intensive course on Canada that covered multiple fields of study. However, they would be wrong. Arguably, such an experience provides more value than a congressional junket to do "fact finding" or "information gathering." Those experiences might provide brief value to a particular piece of legislation, but the CONNECT program provides long-lasting value to generations to come.

The end of our week in Canada did not mean the end of the experience or benefits gained from the program. Since 2003, when the CONNECT program was launched, CONNECT scholars have published more than 50 books. Additionally, in 2010 alone 45 papers across all disciplines were submitted for publication by CONNECT participants (Kirkey 2012). Keep in mind the CONNECT program is only one small part of the Understanding Canada grant program that has had a much larger and wider reach around the world and across disciplines including faculty research funding, dissertation grants, and travel support.

The Understanding Canada program has had significant impact on the two of us as well. From the perspective of Vermont, proximity naturally enables the study of Canada. I started becoming a Canadianist shortly after arriving in the Green Mountain State. I networked north of the border and embraced Canadian culture. I started a Canadian politics course, began the development of an Institute of Canadian Studies, brought Canadian speakers to campus, became involved in the New England Political Science Association's Canadian section, and began doing research. The invitation to the CONNECT seminar provided a splendid opportunity to build on what I started. In particular I have expanded my Canadianist network, including the coauthor of this article, in a variety of domains that has greatly enhanced prospects for all the Canadian irons I have in the fire. Without 
financial support in the form of academic grants, however, none of this would have been possible.

From the perspective of Texas, I grew up as a displaced Canadian-American who had visited family in Canada a half dozen times, but never considered studying Canada. Throughout my life I have had opportunities to learn about the culture and politics of Canada informally. The CONNECT program allowed me to grow as an academic and inspired me to formalize my education about Canada. Since completing the program I have been reading increasing amounts about Canadian politics, engaged in Canadarelated research agendas, and would now be able to teach a collegelevel introductory course on Canadian politics. In essence, this program has brought Canadian studies to Texas through my participation in the CONNECT program, a program financially supported through academic grants.

Christopher Kirkey, director of the Center for the Study of Canada at SUNY Plattsburgh, who runs the CONNECT seminar, informs us that barring a new, unseen funding stream, the July 2012 CONNECT seminar will be the last (Kirkey, Phone Interview 2012).

\section{THE TERMINATION OF THE UNDERSTANDING CANADA GRANT PROGRAM}

On May 1, 2012, Canada's Department of Foreign Affairs and International Trade announced the ending of the Understanding Canada program, a crucial source of funding for Canadianists in countries other than in Canada. The program had been in place since the 1970 and was designed to promote knowledge of Canada and therefore Canadian interests around the world. Moreover, the funds are often the seed money for matching funds and hence contribute to what Patrick James, president of the ICCS, calls "a huge multiplier effect" (Blanchfield 2012). Many have spoken out against the decision. Canadian author Margaret Atwood and 19 other influential Canadian writers ${ }^{1}$ have called for a replacement program (The Globe and Mail 2012a; The Globe and Mail 2012b).

So why was the decision made? The Department of Foreign Affairs and International Trade, in its May 1 announcement, cited "the current fiscal context" as the reason for the decision. Such a rationale is similar to that used by Representative Flake. The explanation comes within the context of the fact that spending has increased $22 \%$ in the first five years of the Harper government's existence (Canadian Government 2011). However, the argument does not consider the noted financial benefits of the Understanding Canada program. In other words, this has the look of a case of being pennywise but pound foolish all under the banner of austerity. It appears the neoliberal chickens have come home to roost squarely on top of the political science profession.

\section{FUNDING THREATS IN THE UNITED STATES}

Not only are academic grants for political science from Canada disappearing, but similar funding threats are seen here in the United States through the actions of Congress. During the last 60 years, academics have relied on government support for research thought the NSF. However, this funding is currently under attack. The siege began on October 13, 2009, when senator Tom Coburn (R-OK) submitted Senate Amendment 2631 to the FY2010 Commerce, Justice, Science, and Related Agencies Appropriations Act. The amendment prevented money from being used for the NSF's political science program. While the amendment lingered for a month, it was not salient to the public at large or the media (Uscinsky and Klofatad 2010). The amendment was soundly defeated by a vote of 36-62, roughly following party lines (U.S. Senate, 111th Congress).

On May 8, 2012, representative Jeff Flake (R-AZ) resumed the assault by offering House Amendment 1058 to the FY2013 Commerce, Justice, Science, and Related Agencies Appropriations Act, which would reduce funding for research and related activities for the NSF by $\$ 1,248,473,000$ (U.S. House. 112th Congress). This amendment was defeated by a vote of 121-291. However, unlike in 2009 more members of Congress were ready to go to bat. Two other amendments were also proposed to make across-the-board cuts. First, representative Marsha Blackburn (R-TN) offered House Amendment 1065 to "reduce total funding in the bill by $1 \%$ across the board," but it failed 160-251 (U.S. House, 112th Congress). Then, representative Paul Broun (R-GA) offered House Amendment 1066 that would reduce funding across the board to each agency and department covered in the bill, except for the Marshals Service, the FBI, and NASA, by $12.2 \%$; this also failed $105^{-}$ 307 (U.S. House, 112th Congress).

After the failure of these across-the-board style cuts, Representative Flake offered a second amendment that specifically targeted political science using the same language as Coburn's 2009 amendment. House Amendment 1094 would "prohibit the use of funds to be used to carry out the functions of the Political Science program in the Division of Social and Economic Sciences of the Directorate for Social, Behavioral, and Economic Sciences of the National Science Foundation" (U.S. House, 112th Congress). Representative Flake argued that "given the economic realities," the \$11 million that the NSF plans to spend toward political science projects is too much, and instead should be zero (Representative Flake (AZ) 2012). Of course, as a percentage of the federal budget, this $\$ 11$ million amounts to less than one-thousandth of a percent $^{2}$ of the $\$ 3.5$ trillion federal budget (U.S. Government 2012). Regardless of how little this effects overall discretionary spending, the amendment passed by a near party line vote of 218-208 with $88.4 \%$ of Republicans supporting the amendment and 95.3\% of Democrats opposing it (U.S. House, 112th Congress).

While S.2323, the senate version of the FY2013 Commerce, Justice, Science, and Related Agencies Appropriations Act has been placed on the calendar, it has not yet been considered. As of June 25, 2012, no decisions have been made on when S.2323 would be considered (Hurst and Young 2012). The delay is due to the investigation of a budget scandal in the National Weather Service, where programmatic funding directed by Congress was diverted to save staff jobs instead (Senator Olympia Snowe (ME) 2012).

At this time the fate of political science funding by the US government is still unknown. On July 31, 2012, senate majority leader Harry Reid (D-NV) and House speaker John Boehner $(\mathrm{R}-\mathrm{OH})$ reached an agreement for a continuing resolution that will extend government funding for six months after it runs out October 1, 2012 (Wasson 2012). This may mean we will have to wait to see the fate of S.2323 for a while. However, in the meantime, we know the fate of the Understanding Canada program and this might be foreshadowing what is to come for us here in the United States.

On March 20, 2013, Senator Coburn proposed a new amendment, S.AMDT.65 to the Consolidated and Further Continuing Appropriations Act, 2013, H.R. 933. This amendment passed by a voice-vote and limits NSF funding discretion for political science 
by requiring funded projects to be "promoting national security or the economic interests of the United States" (U.S. Senate, 111th Congress). On March 26, 2013 the act was signed into law, and with it political science took one of its biggest funding hits. However, this fight is far from over. The Coburn amendment applies only to NSF grants made over the course of the 2013 fiscal year, which comes to and end on September 30, 2013. However, if Congress fails to pass NSF's 2014 spending bill on time, the guidelines would be extended into the next fiscal year (Mervis 2013).

\section{WHY ARE FUNDS UNDER ATTACK?}

As with most social phenomenon, the explanation for these developments is almost certainly multi-causal. There are at least six potential explanations for why funding for the social sciences, and political science in particular, is under attack. The first potential explanation is the one put forth by those proposing and supporting the cuts, namely that budget constraints during tough economic times makes it necessary to trim back government spending. Without a doubt governmental budgets are under strain given the global economic difficulties that many countries are currently facing. When considering the small amounts we are discussing here, for instance the Understanding Canada funding of $\mathrm{C} \$ 5$ million is out of a national budget of $\mathrm{C} \$ 278.7$ billion in 2011, and the $\$ 11$ million from a national budget of $\$ 3.769$ trillion, there have to be other factors that contribute to the cuts, successful or attempted (Canadian Government 2011; U.S. Government 2012).

A second possible reason for what has transpired is the depth to which governmental decision making has become imbued in neoliberal ideology. The application of austerity that has taken that should not be questioned. Social science, as with all the sciences, is driven by skepticism and a need to find evidential support for any assertions. If you already believe all the great truths have been revealed, you will be less likely to see value in investigating the human experience. This is especially the case when such research may undermine the great truths. ${ }^{3}$ Accordingly, political conservatism is a variable worth consideration.

A fourth competing variable is emphasis on mathematics and "hard" science over the social sciences and the humanities. The United States has a long tradition of a utilitarian approach to education (Uhler 2004). This focus on needing only to learn what has immediate practical applicability can have ramifications that go far beyond the scope of this article, but one such outcome is a cultural tradition in the United States that one need only learn about what will prepare one for the job market and thus add productivity to the economy. Other information is considered trivial or academic, suited for use when watching Jeopardy but rarely entering even casual conversation. ${ }^{4} \mathrm{~A}$ seminal education report in 1983, A Nation at Risk, essentially came to the conclusion that the US educational system must emphasize mathematics and science over all other disciplines or the United States will be destined to decline (The National Commission on Excellence in Education 1983). Learning for its own sake is not considered relevant. Obviously the potential explanatory power of this argument may vary in the United States and Canada, but the "math and hard sciences-first educational ideology" is a contending variable.

The fifth potential explanation is tied to the end of the Cold War. With the end of the Cold War and the struggle between the

\section{The most important parts of our job, as we see it, are to (1) uncover patterns and offer rational explanation of the observable world and (2) communicate this knowledge through teaching and other forms of public communication.}

place in response to global economic issues is clearly within a set of neoliberal norms that have been promoted in a "one-size-fitsall" manner by the United States, the World Bank, the International Monetary Fund (IMF), and the European Union (EU), among others. A classic example of these norms can be seen in the IMFs Structural Adjustment Programs (SAP). SAPs are a form of aid to states struggling to finance their budgets and pay their bills with strings of austerity attached. The twentieth century made it clear that there is more than one way to achieve economic success and more than one definition of economic success. Keynesian economics still lives, but you would not know that in the temples of neoliberalism. The adherence to such neoliberal norms smacks of ideological rigidity or the cultural hegemony Marxists have been railing about for decades. Hence, neoliberal ideology may help explain the funding dilemma.

A third possibility is political ideology. In both the United States and Canada, conservatives have been behind the efforts to reduce funding for higher education, especially in the social sciences. There is a logic to this observation when considering the basic tenets of conservatism in general. Conservatism, with its inherent focus on defending the status quo, tends toward supporting traditions and their supports. Traditional values are the great truths
United States and the Soviet Union over all regions of the world, emphasis on regional studies and international relations has substantially declined (Dirks 2012). This dovetails utilitarianism in that politicians may be less likely to believe international studies are of significant relevance.

Finally, we cannot rule out the most common explanation of the cynically minded. Some politicians may simply want to increase secrecy so they can pursue agendas that the public may not find palatable. Dick Cheney's intensive secrecy and lack of transparency regarding decision making may come to mind for some, but there is evidence that this was more than caricature. Other politicians are capable of similar beliefs. After all, history is replete with examples of leaders who bought into the lesser Machiavellian values believing, "the ends justified the means."

Each of these explanations is rational and supported by some evidence. However, each comes with its own holes and can be argued against. Taken together, they paint a picture that illuminates potential motives and justifications for the funding cuts we are seeing today. Obviously this analysis is not the end of the day. Rather it is an attempt to offer potential hypotheses. One thing that is certain is that the politics of the funding of political science can have significant implications. 


\section{WHAT DOES THIS MEAN?}

In many ways, the developments regarding social science funding in Canada and the United States are shots at the very relevance of political science. The cessation of the Understanding Canada program is particularly disturbing when one applies even the most rudimentary cost/benefit analysis. This alarming incident could lead one to conclude that the "wolves are at the door" for our profession and our contribution to the investigation of the human experience. Grants are the lifeblood of research, and research is one of the two core functions of being a political scientist. The most important parts of our job, as we see it, are to (1) uncover patterns and offer rational explanation of the observable world and (2) communicate this knowledge through teaching and other forms of public communication.

To the cynically minded, the concerns expressed here would be interpreted as faculty looking out for their own, immediate concerns. Survival certainly is an issue for academics. Yet to have such a limited view of what is unfolding neglects the vital interests of society both domestic and international. The founding fathers of the United States believed that democracy requires an educated populace, in particular one that can decipher political truth from political fiction. When passion trumps reason, democracy can become what many thinkers over the centuries feared democracy would become ... mob rule. Political education is cru- cut their funding?" We know how that one ends. We may be overly dramatic, but the truth remains that our profession is under threat. It is time to stand up and be counted. We cannot sit idly by while our profession burns.

\section{NOTES}

1. The complete list of writers in order of signing the open letter include: Margaret Atwood, Neil Bissoondath, George Bowering, Dionne Brand, Wayson Choy, Elizabeth Hay, Jack Hodgins, Thomas King, Alistair MacLeod, Rohinton Mistry, Timothy Taylor, Jane Urquhart, Aritha van Herk, Rudy Wiebe, D.M.R. Bentley, Neil Besner, Eva-Marie Kroller, W.H. New, David Staines, and Brian Trehearne.

2. Actual amount is $0.0003 \%$.

3. For discussion of the characteristics of conservatism see David Plazek, 2012, "Ideology Spotting: An Exercise in Teaching Conservatism and Liberalism." The Journal of Political Science Education 8 (2): 168-88.

4. The fact that one meaning of the word academic is essentially "beside the point" we believe speaks volumes about this phenomenon.

\section{REFERENCES}

American Political Science Association. 2012. Core Objectives. http://www .apsanet.org/content_4403.cfm?navID=733 (accessed August 18, 2012).

Blanchfield, Mike. 2012. "Canada Axes Foreign Studies Program Despite Being Told of Economic Spinoffs.” The Globe and Mail, May 16. http://www .theglobeandmail.com/news/politics/canada-axes-foreign-studies-program -despite-being-told-of-economic-spinoffs/article4184581/ (accessed August 16, 2012).

\section{Political education is crucial if democracies are to succeed. In fact it can be easily argued that political research and education are key factors in democracies' political and economic success and survival as it encourages increased knowledge, critical thinking, and an engaged citizenry.}

cial if democracies are to succeed. In fact it can be easily argued that political research and education are key factors in democracies' political and economic success and survival as it encourages increased knowledge, critical thinking, and an engaged citizenry. If we cut back to focus purely on mathematics and (hard) science, we will produce a generation of uncritical technocrats rather than a critically informed and knowledgeable populous.

Plazek (2010) expounded on the importance of normative science and the necessity of action for political scientists. He argued that if the issue at hand is publicly relevant and evidentially significant, political scientists should speak out and try to shape the body politic. We know the word "should" can send shivers down the empiricist's spine. Now is the time to act, however, as the conditions are in place when this is what must be done.

One of the core objectives of our profession listed on the APSA website is: "Serving the public, including disseminating research, and preparing citizens to be effective citizens and political participants" (American Political Science Association 2012). If we are pushed into obscurity or silenced, we cannot fulfill this role and democracy will suffer. If we as political scientists put our heads down and focus only on our immediate concerns, we will do as Nero did and fiddle while Rome burns.

You may say, when they come for the Canadianists, what concern of it is mine as I am not a Canadianist. You may think, "I am not a Canadianist, so why should I be concerned that they have
Bright, Martin. 2006. "NS Interview-Peter Hain.” New Statesman, March 27. http://www.newstatesman.com/node/152881 (accessed August 29, 2012).

Canadian Government. 2011. "Chapter 5: Plan for Returning to Balanced Budgets." Government of Canada, 2011 budget. June 6. http://www.budget.gc.ca/2011 /plan/chap5-eng.html (accessed August 9, 2012).

The Canadian Press. 2012. "Program Cut Despite Evidence of Spinoffs." The Chronicle Herald, May 17. http://thechronicleherald.ca/canada/97139-program -cut-despite-evidence-of-spinoffs (accessed August 1, 2012).

Center for the Study of Canada at SUNY Plattsburgh. 2012. Center for the Study of Canada-Project CONNECT. http://www.plattsburgh.edu/offices/academic /cesca/projectconnect.php (accessed August 9, 2012).

Chenoweth, Erica, and Jason Lyall. 2012. "What NSF Funded Projects Have Taught Us About National Security Issues." The Monkey Cage, May 10. http:// themonkeycage.org/blog/2012/05/10/what-nsf-funded-projects-have-taught -us-about-national-security-issues/ (accessed January 28, 2013).

Dirks, Nicholas B. 2012. “The Chronicle of Higher Education.” Scholars, Spies, and Global Studies, August 13. http://chronicle.com/article/Scholars-SpiesGlobal /133459/ (accessed August 29, 2012).

Fattah, Chaka. 2012. "Amendment Offered By Mr. Flake." Congressional Record, Vol. 158, May 9. H2543.

Flake, Jeffrey. 2012. "Amendment Offered By Mr. Flake.” Congressional Record, Vol. 158, May 9, 2012. H2543.

Gelman, Andrew. 2012. "What Your NSF Dollar Gets You: Understanding of Public Opinion and Technological Spinoffs." The Monkey Cage, May 11. http:// themonkeycage.org/blog/2012/05/11/what-your-nsf-dollar-gets-you -understanding-of-public-opinion-and-technological-spinoffs/ (accessed January 28, 2013).

The Globe and Mail. 2012b. "Authors, Academics Urge Federal Government to Replace 'Understanding Canada.'” The Globe and Mail, June 20, 2012. http:// www.theglobeandmail.com/arts/books-and-media/authors-academics-urge -federal-government-to-replace-understanding-canada/article 4358367 / (accessed August 1, 2012). 
. 2012a. "Understanding Canada No More." The Globe and Mail, June 19, 2012a. http://www.theglobeandmail.com/commentary/columnists /understanding-canada-no-more/article 4332911 (accessed August 1, 2012).

Hurst, Nathan, and Kerry Young. 2012. "Spending Bills Pass in House, Lag in Senate." Congressional Quarterly, June 25. http://public.cq.com/docs/news /news-0oooo4112616.html (accessed August 20, 2012).

Kirkey, Christopher. 2012. "New Voices on Canada-The CONNECT Program." American Review of Canadian Studies 42 (2): 125-29.

Kirkey, Christopher. 2012. Interview by David Plazek. Phone Interview (August 9).

Martin, Paul. 2012. “Canada's Image Abroad: Fade to Black-The Elimination of the Understanding Canada Program is a Heartbreaking and Unfathomable Blow to Canadian Studies Worldwide." University Affairs, June 6. http:// www.universityaffairs.ca/canadas-image-abroad-fade-to-black.aspx (accessed August 15, 2012).

Meisel, John, and John Graham. 2012. "It's Hard to Understand Canadian Studies Cuts." The Globe and Mail, July 12. http://www.theglobeandmail.com /commentary/its-hard-to-understand-canadian-studies-cuts/article4408869 (accessed August 2, 2012).

Mervis, Jeffrey. 2013. "Congress Limits NSF Funding for Political Science." Science 339 (6127): 1510-511.

The National Commission on Excellence in Education. 1983. A Nation at Risk: The Imperative for Educational Reform. Washington, DC: Government Printing Office.

Nyhan, Brendan. 2012. "The Importance of NSF Funding for Political Science." May 15. http://www.brendan-nyhan.com/blog/2012/o5/nsf-funding-for -political-science-.html (accessed January 28, 2013).

Plazek, David. 2010. "Where the Rubber Meets the Road: The Role of Collegiality and Normative Science in Our Profession." PS: Political Science and Politics 43 (2): 333-36.

Snowe, Olympia. 2012. "Snowe Calls for Action in Wake of Reported Mismanagement of National Weather Service Funding." Press Release, May 25. http://
www.snowe.senate.gov/public/index.cfm/pressreleases?ContentRecord _id = 96644921-377d-4cao-ab8f-f5dd5f64f1a9 (accessed August 20, 2012).

US Government. 2012. "Budget of the U.S. Government.” U.S. Government Printing Office. February 13. http://www.gpo.gov/fdsys/search/pagedetails .action?packageId=BUDGET-2013-BUD (accessed August 20, 2012).

US House. 112th Congress. H.AMDT. 1066, ONLINE. n.d. http://thomas.loc.gov /cgi-bin/bdquery/z?d112:hz1066: (accessed August 6, 2012).

- H.AMDT. 1058, ONLINE. n.d. http://thomas.loc.gov/cgi-bin/bdquery /z?d112:HZo1058 (accessed August 6, 2012).

- H.AMDT. 1065, ONLINE. n.d. http://thomas.loc.gov/cgi-bin/bdquery /z?d112:hz1065: (accessed August 6, 2012).

.H.AMDT. 1094, ONLINE. n.d. http://thomas.loc.gov/cgi-bin/bdquery /z?d112:hz1094: (accessed August 6, 2012).

Uhler, Walter C. 2004. "Democracy or Dominion?" Bulletin of the Atomic Scientists 60 (January): 52-58.

Uscinsky, Joseph E., and Casey A. Klofatad. 2010. "Who Likes Political Science? Determinants of Senators' Votes on the Coburn Amendment." PS: Political Science \& Politics 43 (4): 701-06.

US Senate. 111th Congress. S.AMDE.2631, ONLINE. n.d. http://thomas.loc.gov /cgi-bin/bdquery/z?d111:SP2631: (accessed August 9, 2012).

US Senate. 111th Congress. S.AMDE.65, ONLINE. n.d. ttp://thomas.loc.gov /cgi-bin/bdquery/z?d113:SPo65: (accessed April 9, 2013).

Wasson, Erik. 2012. "Reid, Boehner Announce Deal to Avoid Government Shutdown." The Hill, July 31. http://thehill.com/blogs/on-the-money/appropriations /241277-leaders-expected-to-announce-spending-bill-agreement (accessed August 21, 2012)

Wilson, Rick. 2012. "What Has the NSF Wrought." The Monkey Cage, May 15. http://themonkeycage.org/blog/2012/o5/15/what-has-the-nsf-wrought/ (accessed January 29, 2013). 